\title{
Regarding the descemetorhexis for anterior synechiolysis prior to endothelial keratoplasty
}

This article was published in the following Dove Press journal:

Therapeutics and Clinical Risk Management

\section{Sang Beom Han}

Department of Ophthalmology, Kangwon National University Hospital, Kangwon National University Graduate School of Medicine, Chuncheon, Republic of Korea
Correspondence: Sang Beom Han Department of Ophthalmology, Kangwon National University Hospital, I56 Baengnyeong-ro, Chuncheon, Kangwon 200-722, Republic of Korea Tel +82332589210

Fax +82 332582296

Email m.sangbeom.han@gmail.com

\section{Dear editor}

We read with great interest the article by Droutsas et al entitled "Isolated descemetorhexis for anterior synechiolysis prior to endothelial keratoplasty - case report and technique." The authors introduced an interesting case in which isolated descemetorhexis was first performed for the management of flat anterior chamber and extensive iridocorneal synechiae, and subsequently Descemet stripping endothelial keratoplasty (EK) was successfully done for visual rehabilitation. ${ }^{1}$ This stepwise approach is expected to be helpful for restoration and maintenance of corneal clarity. ${ }^{1}$ The authors also employed an useful method of scoring of Descemet's membrane by using a reverse Sinskey hook (D.O.R.C., Zuidland, the Netherlands) after filling the anterior chamber with air. As previous studies have suggested, Descemet's membrane stripping under air, instead of viscoelastic material, can improve visualization, even in corneal opacity due to bullous keratopathy. ${ }^{2,3}$ We believe the technique was helpful for preventing damage to adjacent tissue and reducing postoperative inflammation.

In this case, EK appeared to be challenging due to shallow anterior chamber and anterior synechiae. Although the authors did perform excellent surgery, we would like to recommend that employment of an anterior chamber maintainer could be helpful.

The authors did a vitrectome-assisted membranectomy for restoration of a round and unoccluded pupil 1 month after the EK. Although the procedure might be simple and less invasive, there is a concern that repetitive intraocular surgery could lead to endothelial cell damage. We would like to suggest that noninvasive methods, such as lysis of the pupil-occluding membrane using Nd:YAG laser, can also be considered as alternatives. ${ }^{4}$

We would also like to point out that close monitoring of intraocular pressure is mandatory after the EK for prevention of endothelial cell damage and graft failure, especially because the patient has prior history of trabeculectomy and severe iridocorneal synechiae.

\section{Disclosure}

The author reports no conflicts of interest in this communication.

\section{References}

1. Droutsas K, Andreanos K, Lazaridis A, Georgalas I, Kymionis G, Papaconstantinou D. Isolated descemetorhexis for anterior synechiolysis prior to endothelial keratoplasty - case report and technique. Ther Clin Risk Manag. 2017;13:1443-1447. 
2. Gabbay IE, Bahar I, Nahum Y, Livny E. Comparison of descemet stripping under continuous air flow, manual air injection and balanced salt solution for DMEK: a pilot study. Graefes Arch Clin Exp Ophthalmol. 2017;255:1605-1611.

3. Mehta JS, Hantera MM, Tan DT. Modified air-assisted descemetorhexis for descemet-stripping automated endothelial keratoplasty. J Cataract Refract Surg. 2008;34:889-891.
4. Kim ES, Kim M, Lee SJ, Han SB, Yang HK, Hyon JY. Postoperative occlusion of visual axis with fibrous membrane in the presence of anterior capsular phimosis in a patient with pseudoexfoliation syndrome: a case report. BMC Ophthalmol. 2016;16:213. 


\section{Authors' reply \\ K Droutsas ${ }^{1,2}$ \\ K Andreanos' \\ A Lazaridis ${ }^{2}$ \\ I Georgalas' \\ G Kymionis ${ }^{1,3}$ \\ D Papaconstantinou'}

'First Department of Ophthalmology, National and Kapodistrian

University of Athens, Athens, Greece; ${ }^{2}$ Ophthalmology

Department, Philipps University Marburg, Marburg, Germany;

${ }^{3}$ Ophthalmology Department, Jules Gonin Eye Hospital,

University of Lausanne, Lausanne, Switzerland

Correspondence: K Andreanos

First Department of Ophthalmology, National and Kapodistrian

University of Athens, 22str Digeni E.O.K.A, Nea Penteli,

Athens 15236, Greece

Tel +306955477921

Email coandre80@icloud.com

\section{Dear editor}

We would like to thank Dr Han for the valuable comments on our article entitled "Isolated descemetorhexis for anterior synechiolysis prior to endothelial keratoplasty - case report and technique."

We agree that the air-to-endothelium interface drastically improves visualization of Descemet's membrane as pointed out in previous reports. ${ }^{1,2}$ However, due to the extent of central synechiae, an adequate anterior chamber depth could not be maintained by air until after removal of the majority of synechiae.

Concerning the use of an anterior chamber maintainer, we indeed routinely insert this device in Ultrathin-DSAEK procedures to facilitate atraumatic insertion of the endothelial lenticle with the Busin glide and forceps as described previously. ${ }^{3,4}$ This was not described in the present report in detail in order to emphasize on the synechiolysis technique.
Apart from that, the anterior chamber depth had been fully restored before the DSAEK procedure.

Furthermore, we agree that Nd:YAG laser-assisted perforation of the pupillary membrane could have been applied instead of a vitrectome-assisted membranectomy. However, as we mention in the article, the iridocorneal tissue in the pupillary plane appeared to be stiff and thick. Therefore an $\mathrm{Nd}$ :YAG laser procedure did not seem adequate to provide the desired results. Moreover, in order to clear the visual axis from the iridocorneal remnants, a large amount of energy and number of laser spots would have been necessary. This could have caused severe inflammation in the eye jeopardizing the clarity of endothelial keratoplasty graft and the function of the filtering bleb. ${ }^{5}$ Finally, the described approach also offered a round pupil with restored motility.

\section{Disclosure}

The authors report no conflicts of interest in this communication.

\section{References}

1. Droutsas K, Giallouros E, Melles GR, Chatzistefanou K, Sekundo W. Descemet membrane endothelial keratoplasty: learning curve of a single surgeon. Cornea. 2013;32(8):1075-1079.

2. Dapena I, Moutsouris K, Droutsas K, Ham L, van Dijk K, Melles GR. Standardized "no-touch" technique for descemet membrane endothelial keratoplasty. Arch Ophthalmol. 2011;129(1):88-94.

3. Ciechanowski PP, Droutsas K, Baydoun L, Dirisamer M, Oellerich S, Melles GR. Standardized descemet membrane endothelial keratoplasty (DMEK): technique and latest results. Ophthalmologe. 2014;111(11): 1041-1049.

4. Droutsas K, Lazaridis A, Papaconstantinou D, et al. Visual outcomes after descemet membrane endothelial keratoplasty versus Descemet stripping automated endothelial keratoplasty-comparison of specific matched pairs. Cornea. 2016;35(6):765-771.

5. Diagourtas A, Petrou P, Georgalas I, et al. Bleb failure and intraocular pressure rise following Nd:Yag laser capsulotomy. BMC Ophthalmol. 2017;17(1):18.

Dove Medical Press encourages responsible, free and frank academic debate. The content of the Therapeutics and Clinical Risk Management 'letters to the editor' section does not necessarily represent the views of Dove Medical Press, its officers, agents, employees, related entities or the Therapeutics and Clinical Risk Management editors. While all reasonable steps have been taken to confirm the content of each letter, Dove Medical Press accepts no liability in respect of the content of any letter, nor is it responsible for the content and accuracy of any letter to the editor.

\section{Publish your work in this journal}

Therapeutics and Clinical Risk Management is an international, peerreviewed journal of clinical therapeutics and risk management, focusing on concise rapid reporting of clinical studies in all therapeutic areas, outcomes, safety, and programs for the effective, safe, and sustained use of medicines. This journal is indexed on PubMed Central, CAS,
EMBase, Scopus and the Elsevier Bibliographic databases. The manuscript management system is completely online and includes a very quick and fair peer-review system, which is all easy to use. Visit http://www.dovepress.com/testimonials.php to read real quotes from published authors. 